\title{
Educational therapy of adolescent idiopathic scoliosis treated by brace
}

\author{
Jean-Claude Bernard ${ }^{1 *}$, Julie Deceuninck ${ }^{1}$, Muriele Schneider ${ }^{1}$, Laurence Moisson ${ }^{1}$, Audrey Combey ${ }^{1}$, Rachel Bard ${ }^{1}$, \\ Anne-Lise Nogues ${ }^{1}$, Laurence Burel ${ }^{1}$, Gregory Notin², Lydie Journoud ${ }^{2}$ \\ From 11th International Conference on Conservative Management of Spinal Deformities - SOSORT 2014 \\ Annual Meeting \\ Wiesbaden, Germany. 8-10 May 2014
}

\section{Introduction}

Adolescent idiopathic scoliosis treated by brace assent with The Patient Educational Therapy (PET) according to the "ARS" in 2013.

\section{Inclusion}

Adolescents between 12 and 15 years old with a tolerance for younger children who are still in adolescent problematic. Evolutional scoliosis diagnosis and orthopedic treatment indication.

\section{Objectives}

Improve compliance.

Improve understanding about scoliosis and its progress.

Preserve quality of life.

Course.

Educational diagnosis during the week of brace adaptation.

PET program is shape by 5 workshop on 1 day: expression group between adolescents, around the brace, experience about daily life with the brace, physical activity with brace, expression group between parents.

\section{Discussion}

The PET objectives engage the adolescent, his parents, his physiotherapist and his physician on the conservative treatment of scoliosis and allow each of them to acquire adaptability capacities and self-care capacities. Evaluation questionnaires completed by the adolescent and his parents are in analysis.

${ }^{1}$ CMCR des Massues, Lyon, France

Full list of author information is available at the end of the article
Authors' details

${ }^{1}$ CMCR des Massues, Lyon, France. ${ }^{2}$ Ets Lecante, Lyon, France.

Published: 4 December 2014

doi:10.1186/1748-7161-9-S1-P1

Cite this article as: Bernard et al:: Educational therapy of adolescent

idiopathic scoliosis treated by brace. Scoliosis 2014 9(Suppl 1):P1.
Submit your next manuscript to BioMed Central and take full advantage of:

- Convenient online submission

- Thorough peer review

- No space constraints or color figure charges

- Immediate publication on acceptance

- Inclusion in PubMed, CAS, Scopus and Google Scholar

- Research which is freely available for redistribution

Submit your manuscript at www.biomedcentral.com/submit
( Biomed Central 